Keirl, S., (2017), 'Critiquing as Design and Technology curriculum journey: history, theory, politics, and potential' in Williams, J. \& Stables, K., (Eds.), (2016 Forthcoming), Critique in Technology Education, pp. 109-133, Springer, Dordrecht.

\title{
Critiquing as Design and Technology curriculum journey: history, theory, politics, and potential
}

\author{
Steve Keirl
}

Goldsmiths, University of London

s.keirl@gold.ac.uk

\begin{abstract}
Critiquing, as a key component of Design and Technology (D\&T) education, made its global debut fifteen years ago in the re-designed South Australia curriculum. It has since gained international recognition for its validity for the education of all children. This chapter sets out the story of critiquing as Design and Technology curriculum phenomenon and, while the story reports a personal research journey, it was the work of a dedicated team that brought the curriculum as a whole to fruition. Key episodes of the story address: curriculum research method as autobiography; the politics of D\&T curriculum; the theoretical underpinnings of the critiquing innovation; its local, national and international contexts; the curriculum challenges its introduction was intended to resolve; and, some consequent theorisation since its inception. In this story, 'Design and Technology' is seen as much more than a school 'subject'. It is argued that critical-ethical design-and-technological literacy is necessary if sustainable, democratic futures are to be achieved. Critiquing is fundamental to such literacy.
\end{abstract}

\section{Keywords}

Critiquing; Critical pedagogy; Curriculum; Technological literacy; Design literacy

\section{Introduction}

When critiquing became central to the South Australian Design and Technology (D\&T) curriculum in 2001 it was a world first. No D\&T curriculum had ever made such a move - one that expected critiquing, along with designing and making, to permeate all D\&T pedagogy and learning.

The Design and Technology Learning Area is articulated through three strands. These reflect the processes of thinking and doing that constitute a quality education common to any technology (eg agriculture, architecture, information and communication technology, electronics, engineering, food, genetics, media, robotics, textiles, viticulture). The three strands are:

- Critiquing

- Designing

- Making

These three strands are interdependent and none of them is predominant. Read alongside each other they do not constitute a sequential process... A quality Design and Technology education weaves the three into a dynamic and holistic learning experience for all students.

(DETE, 2001a\&b. My italics)

Like many curriculum innovations, critiquing got a varied reception - locally, nationally and internationally. Reactions ranged from cynicism, through hesitant acceptance, to those who could immediately see its educational validity. Today, as this book attests, the story is different. Critique, as both noun and verb, is now recognised for its validity as a vibrant component of best D\&T practice. Critiquing as documented in this chapter was developed as a properly theorised curriculum inclusion, intentionally problematic and pedagogically challenging. It was never intended as a vanilla version of 
product appraisal, tick-box reflection, or as a casual curriculum add-on. As a defensible educational practice, critiquing is far more than this. Critiquing emerged from substantial research and it continues to demand research.

I begin by outlining some personal engagements with, and orientations toward, critiquing and curriculum research. I then describe the theoretical underpinnings of critiquing - so necessary for its advocacy and defence for inclusion in politically contested curricula. Moving through international, national and local settings, I set out the educational and geo-political context for the (then) innovation before presenting an overview of the South Australian curriculum. This backgrounding, is necessary for a proper understanding of critiquing's theoretical rigour and its educational potential for all. I close with a selection of theorisations, reflections and developments that have resulted from the original innovation. The chapter can't accommodate full detail of all aspects of this curriculum journey but sources are given wherever possible.

\section{Curriculum work as personal journey and autobiographical method}

As leading international curriculum theorist, Pinar has said: 'Our pedagogical work is simultaneously autobiographical and political.’ (Pinar, 2004/2008:4). I partly describe my own motivations thus:

As a species we are unable to define or describe ourselves without reference to technologies. Our very existence is dependant on, and inter-dependent with, technologies. The quality of our co-existence with other species and the planet cannot be determined without technological critique. Why is it then, when the phenomenon of technology constitutes such a pervasive and hegemonic part of life on the planet, that it is so ill-addressed in education? This is the question that drives my own curriculum enquiry. (Keirl, 2007d:77)

The genre of The Critical has engaged me since Philosophy of Education seminars with an excellent lecturer (Bernard Down) in the 1970s in England. Early appreciations of both philosophy-as-critique and critical thinking as keys to educational theory, policy-making and pedagogy were natural antecedents to my early-1990s introduction to Critical Theory at the University of Tasmania and, subsequently, to its application to curriculum, pedagogy and literacy at the University of South Australia. Whether in advocating critical practice in D\&T through critiquing as curriculum dimension (Keirl, 1997a\&b), or in arguing for ethical technological literacy (Keirl, 2006), theorising 'the critical as educational tool' has remained central to my curriculum research journey.

But what of the political? There are two realms here - the politics of education and the politics of technology. For me, they meet around questions of democracy and what should constitute a proper and defensible Design and Technology education for every child, across the planet. Education, and D\&T as a component of it, is a political act (Layton, 1994; Petrina, 2000a; Keirl, 2006; 2007c) and I believe that D\&T must continuously critique itself in at least two ways. One is in how it is politically constituted as an educational field by external agencies as much as by its own players. I have attempted more recently to articulate a case for a role for D\&T as agent against neoliberalism (predatory capitalism) in defence of sustainability (Keirl, 2015a). Linked with this, is the need for D\&T to maintain its political sensibilities around how it contributes (or otherwise) to global democratic citizenship (Keirl, 1999/2001; 2006). For me, these political necessities preface and inform any other D\&T curriculum considerations. On technology, as Feenberg says: 'The fate of democracy is...bound up with our understanding of technology.' (Feenberg, 1999:vii)

Within all of this is the self using the theoretical and the philosophical as tools to advance and establish new practices. Pinar notes that: '(The) "theoretical relationship" with oneself can be explored and recast through autobiographical reflection, through conversation with oneself' (Pinar, 2004/2008:251). Ultimately, the personal, the theoretical and the political cease to be mere categories. They become one's (and Design and Technology's) holistic engagements with the existential, as personal lived experience (van Manen, 1990; Morris, 1966/1990) as well as with one's co-existences (Keirl, 2010). However, the self and the critical also interplay and, as ever in research, considerations of bias and prejudice arise. I declare my bias when I argue my case against D\&T as, for example, 
skilling, vocational education, gendered roles, preparation for a destructive and divisive economic system, and more. I declare my bias when I argue my case for D\&T for sustainable futures, democratic life, dynamic curriculum, ethics, design education, and a critical disposition. (Keirl, 2001b)

I draw on Pinar's curriculum scholarship (2004/2008; 2007) and his 'method of currere' (the Latin root of 'curriculum') as ' ... an autobiographical method asks us to slow down, to remember even reenter the past, and to meditatively imagine the future.' (Pinar, 2004/2008:4). This, he offers, is a matter of the reconstruction of self and society alike and he talks of the 'nightmare' we are living and how we '...believe in education (yet) we see how powerfully schooling crushes it...' (Pinar, 2004/2008:127). Pinar is not alone as a curriculum theorist who sees persons as central to education; who takes a critical stance (self-critical as well as socially-critical) towards curriculum thinking and action; and who valorises the educator as intellectual activist (see e.g. Freire, 1972; 2001; Postman \& Weingartner, 1969/1971; Apple, 1979; Giroux, 1983; Goodson \& Walker, 1991; Blackmore, 2002; Smith \& Lovat, 1991; Pinar, 2007; Kincheloe, 2008/2010; Darder et al., 2009a; Smyth, 2011). All such curriculum workers eschew simplistic and instrumental conceptions of curriculum and they subscribe to Pinar's articulation of 'curriculum as complicated conversation':

The method of currere reconceptualized curriculum from course objectives to complicated conversation with oneself (as a "private" intellectual), an ongoing project of self-understanding in which one becomes mobilized for engaged pedagogical action - as a private-and-public intellectual - with others in the social reconstruction of the public sphere. (Pinar, 2004/2008:37)

Critiquing is this chapter's focus and, despite twenty years of D\&T curriculum work around critiquing and critical technological literacy, there remains much to achieve. I value Canby's ninety-year-old insight not only for what it says about criticism but for its resonance with Technology Education's multiple players:

One reason why football is more satisfactory than criticism is that there is only one ball. In criticism, too often everyone brings his (sic) own ball, and when he pushes it over the goal line thinks he has won the game. (Canby, 1924/1967:226)

As part of D\&T's own complicated conversations, critiquing cannot be seen as an isolated piece of a curriculum jigsaw. It must be understood as permeating all designerly and technological behaviours and circumstances. Critiquing is necessarily of the complex and of the holistic. It was never some isolated concept plucked from the air, chosen to be fashionable, or as a quick fix for a particular curriculum problem. Critiquing in D\&T has run a fifteen-year journey grounded in a proper rationale and theorisation that continue to be revised and refined.

While some curricular innovations are trends that occur concurrently across the globe, others (such as critiquing) have arisen in a specific jurisdiction at a specific time under specific conditions. For D\&T, there are two broad temporal considerations regarding critiquing: how it might apply in the immediate study-space, for example, when designing; and, how it contributes to learning for life - whether or not associated with design activity. It is invaluable '... both to designing and to the interrogation of the values and merits of extant technologies, products and systems. The nurturing of a critiquing disposition serves specialist Design and Technology Education and generalist education for democratic life equally well.' (Keirl, 2009)

\section{Critical-theoretical underpinnings}

The introduction of critiquing into the D\&T curriculum was informed by Critical Theory whose global educational influence is most strongly evidenced in critical literacy and critical pedagogy.

Critical theorists begin with the premise that men and women are essentially unfree and inhabit a world rife with contradictions and asymmetries of power and privilege. The critical educator 
endorses theories that are, first and foremost, dialectical; that is, theories that recognize the problems of society as more than simply isolated events of individuals or deficiencies in the social structure. (McLaren, 1989/2009:61)

Two of Critical Theory's greatest protagonists, Freire (1972; 2001) and Habermas (1971), have been particularly influential in education. By suggesting that we hold three kinds of 'cognitive interests', Habermas (1971) opened a door to understanding the world-as-lived, how power is (ill-)distributed, and how we can act. He wrote of ' ...the task of a critical philosophy of science that escapes the snares of positivism. The approach of the empirical-analytic sciences incorporates a technical cognitive interest; that of the historical-hermeneutic sciences incorporates a practical one; and the approach of the critically oriented sciences incorporates the emancipatory cognitive interest...' (Habermas, 1971:308 My italics). Unsurprisingly, one methodology of the Habermasian approach is ideology critique tackling the values, beliefs and practices of particular dominant groups (Morrison, 2001).

It is one thing to operate in and on the world at a technical level of facts and utility; another to be able to interpret the world and experience; and yet another to see it as emancipatory - building on both the technical and the practical but ultimately being liberated from (technological) structures and regimes that dominate our ways-of-being. All designed technologies are enactments of human decisionmaking and they amount to being assemblages of values. Rampant consumerism, unsustainability, environmental destruction, multiple anti-democratic practices, and more, are sites for technological critique of just whose interests are being served and what our personal positioning and responsibilities might be.

Morrison (2001) shows how the three knowledge-constitutive interests can influence curriculum design. The 'rationalist/behaviourist' view of curriculum values the bureaucracy-driven, heavily tested, curriculum-as-instrument. A 'curriculum as practice' is humanistic, interpretive and pragmatic, it privileges understanding over outcomes, and its hermeneutic knowledge interest optimises genuine experiential learning. 'Curriculum-as-praxis' takes an 'existential, empowering and ideology-critical' approach that is emancipatory in nature. In advancing the emancipatory aspect, curriculum is problematised by all involved - not least the students. (Morrison, 2001:218). Such an approach is implicitly political and necessarily controversial as it commits to challenging the dominant ideology (Keirl, 2015a). Applying the critical lens of Habermas's knowledge interests to D\&T curricula highlights how seriously limited many are - often (even intentionally) fulfilling only the technical interest.

Critical Theory has been richly applied to education in many ways (McLaren, 1989/2009; Emmitt \& Pollock, 1991; Kemmis, 1991/2005; Comber, 1992; Aronowitz \& Giroux, 1993; Comber, 1994; Comber et al., 1998; Morrison, 2001; Kellner, 2003; Smith \& Lovat, 2006). Kemmis (1991/2005), points out that: '...critical theorists themselves are suspicious of any "grand narrative" of history...' and he notes how: '...critical theorists... have been both critical and self-critical...' (Kemmis, 1991/2005:314). Giroux (1983), a leader in bringing critical theory to education, argued the importance of critiquing the positivist and functionalist rationality dominant in schools.

Rather than celebrating objectivity and consensus, teachers must place the notions of critique and conflict at the center of their pedagogical models...Critique must become a vital pedagogical tool - not only because it breaks through the mystifications and distortions that "silently" work behind the labels and routines of school practice, but also because it models a form of resistance and oppositional pedagogy. (Giroux, 1983:62)

\section{The critical literacy movement}

Freire's (1972) landmark pedagogical critique showed how education in the dominant Western model maintains a status quo of conformity and control through disproportionate power distribution. Famously, he contrasted 'banking education' with 'problem-posing education' (for D\&T, 'skilling' 
compared with 'design and action-on-the-world'.) Critical literacy theorists have shown how different interests were served by different approaches to literacy. For example:

The link between literacy and economic rationalism has a long, if not altogether distinguished, history... There are powerful economic and political precedents and parallels for current social policy in Australia. In those countries with conservative governments...educational and social policies have stressed a binary approach to literacy: 'cultural literacy' based on the Anglocolonial literary canon for an elite.... and 'functional literacy' for everyone else (i.e. 'survival' skills for the emergent underclass). (Luke, 1992:3)

Witness, then, Technology Education formulations that ensure elites of designers, programmers, architects and engineers alongside a mass of skilled and semi-skilled operatives. McLaren saw this as: '...reproducing dominant class interest directed towards creating obedient, docile, and low-paid workers.' (McLaren, 1989/2009:62). A significant literacy milestone came from the New London Group (NLG, 1996), an international collaboration of ten literacy scholars, five of whom, including Luke, were Australian. Their influential work on 'multiliteracies' prompted speculation for Design and Technology Education:

Interestingly, on their journey of deliberation of the 'state of literacy pedagogy', this group make use of the 'key concept' of 'Design' and discover that "... as designers of meaning, we are designers of social futures - workplace futures, public futures, and community futures" (NLG, 1996:65)...The New London Group, in moving on from 'mere literacy' advance the idea of 'multiliteracies'. Thus we might accept multiple and changing meanings of technology rather than searching for a grail articulated through a single definition. (Keirl, 1999a:75)

Concurrently, Petrina (2000b) gave critical technological literacy an appropriate mainstream debut. D\&T still has a long way to travel to embrace the propositions and issues presented in that article. However, early formulations of a Habermasian critical technological literacy (Keirl, 1996; 1997a; 1999b) fed into the South Australian curriculum development and were subsequently developed as an ethical technological literacy advocating critical curricula and pedagogies in the defence of democratic existences. (Keirl, 2006)

The end of the 20th Century had witnessed the growth of a global movement in critical theory and critical literacy theory and the Australian chapter was vibrant - not least a strong South Australian grouping of critical literacy theorists. Meanwhile, globally, negative reactions emerged against such liberatory theorising - a political backlash from the right with its politics of the (uncritical, unproblematic) soundbite of the 'back to basics' kind. (For critiques of this drive not only to control and shape education but to silence opposition, see, for example, Aronowitz \& Giroux, 1993; Coomber et al., 1998; Lankshear, 1998; Apple, 2001; Smith, 2003; Pinar, 2003, 2004/2008, 2007; Reid, 2004/2005; Darder et al., 2009b; Smyth, 2011; and, on Design and Technology: Petrina, 2000a, 2000b, 2003; Keirl, 2006, 2015a\&b).

\section{Critical pedagogy in context}

Darder et al. (2009b) remind us that critical pedagogy must be understood as part of '... a long tradition of progressive educational movements and on-going struggles of reinvention...' and they caution against any '.. temptation to inadvertently reify and reduce critical pedagogy to a teaching "method"" (Darder et al., 2009b:19). Critical pedagogy is no more or less political in its aims and practices than that of neoliberalism whose agenda: seeks to homogenise the educational experience of the masses; is competition-driven; demands high-stakes testing for 'accountability'; treats education as a business; creates artificial decentralisation; severely constrains teachers' professionalism; promulgates a misperception of 'failure' of students, schools and teachers alike; and, promotes curriculum determination by non-educational groups, nationally and internationally, in support of internationalised labour markets (Smith, 2003; Keirl, 2015a). 
D\&T's curriculum and pedagogy are embroiled in this dehumanising strangulation of education and D\&T has a simple option: to do very little (or nothing at all) and to have its lot determined in ways that advance the neoliberal agenda, or, to exercise some self-determination over its educational role and purposes. 'Self-determination' need not mean selfish determination. Properly understood and justified, any 'subject' has duties towards both specialist and general education. Year-on-year we are deepening our understandings of how rich D\&T contributes to the education of all students in terms of identity, citizenship, capability, critical awareness, and more. This is D\&T's contribution to students, to society, and to global democracy and it is fundamentally a matter of ethics (Keirl, 2006; 2015b). D\&T's special role concerns the designed and made world and the host of accompanying issues demand that it has its own particular critical pedagogy - one that explores, exposes and declares multiple technical-instrumental, interpretive-hermeneutic, and critical-emancipatory technological interests.

The global influences of critical theory, critical literacy and critical pedagogy were one politicoeducational phenomenon of the late $20^{\text {th }}$ Century. However other circumstances and considerations warranted the critiquing innovation too.

\section{Global influences on technology curricula}

In the 1990s, issues of sustainability, globalisation, and emergent technologies all achieved growing, if uncritical, attention (Keirl, 2002b\&c). Despite public concern, positive change remained negligible. Running though all of these is an obvious ethical thread but there was a democratic concern too. Almost all the issues were technology-related. While societies, communities and individuals continued to be 'shaped' by technological developments, public engagements with technological design decision-making was as remote as ever. Democracy, itself a technology, was (and remains) threatened, being perversely linked to 'economy', while privacy was being negated, surveillance increased, and criticism and protest demonised. (Keirl, 2006; 2015a\&b)

Technological developments (artificial intelligence, robotics, genetics, nanotechnologies, communications technologies, so-called 'social' media, and more) were not only emergent but increasingly convergent. The humanising of technologies and the technologising of humans together inform discussion of the end of humanity, post-humanism and transhumanism (Keirl, 2015a\&b). The 1970s and 1980s had seen the sanctioned decline of craft education in schools whilst, today, its existential benefits invite educational argument for inclusion. Subsequently, consciousness and criticism became topics $d u$ jour with regard to democracy and technology. For example: ' ...not so long ago it was fashionable for social critics to condemn technologies as such...Increasingly, however, social criticism has turned to the study and advocacy of possible reconfigurations and transformations of technology to accommodate it to actors excluded from the original design networks.' (Feenberg, 2010:77). In 1999 Postman argued his (Enlightenment) case for the need for skepticism in general and in education in particular: 'Modern educators do not usually use the word, preferring something like "critical thinking". But in any case, they do not do much about it. There are several reasons why. The first is that it is dangerous...' (Postman, 1999/2000:159-160). In 1995, Sclove argued for: '...a democratic theory of technology... using political philosophy to develop prescriptions for technological design and choice...(and)...challenging the foundations of modern economic thought...(with the aim of helping) achieve citizenship in a future world of democratic technology.' (Sclove, 1995:x-xi).

Meanwhile, Saul (1995) had shown how decision-making in society had moved away from the individual and democracy towards conformity and corporatism, where decisions are made through constant negotiations between specialist interest groups. He outlined The Great Leap Backwards: '...our leap into the unconscious state beloved of the subject who, existing as a function in any one of the tens of thousands of corporations - public and private - is relieved of personal, disinterested responsibility for his (sic) society. He thus gives in to the easy temptation of embracing what I can only call the passive certitude offered by every ideology.' (Saul, 1995:37). He signals the importance of confronting reality and how this: '... usually is a negative process. It is ideology that insists upon 
relentless positivism. That's why it opposes criticism and encourages passivity.' (Saul, 1995:38). And he defends '....(his)...Socratic right - to criticize, to reject conformity, passivity and inevitability.' (Saul, 1995:39). There is little in Saul's 'unconsciousness' thesis that is not directly applicable to our designed technologies and to our technologically mediated worlds.

\section{Critiquing technologies and design}

For assessments of technologies, a Habermasian critiquing cannot stop at the traditional positivist question of "Does it work?" (the technical level) but must go further into the hermeneutical, interpretive explorations that effect meaning-making and, further, into the critical-emancipatory engagements that facilitate the existential and the liberatory. Critiquing is not mere analysis: it is inward- and outward-directed interrogation; it debunks, demystifies and exposes power relations too. 'Critical theory (can be) a highly reflexive enterprise - it is never satisfied with asking what something means or how it works, it also has to ask what is at stake in asking such questions in the first place.'

(Buchanan, 2010:100)

The ever-growing literature on philosophy and sociology of technology, and of design, provides rich grounds for D\&T educational research. Here, I nominate just two authors. Feenberg's (1991) Critical Theory of Technology was followed by over twenty years of deep critical theorising of technology (e.g. Feenberg, 1999; 2010). Offering important critiques of Heidegger and Habermas, he notes two 'substantive' theories of technology and argues that technology's pervasiveness in our lives is such that:

...one can draw diametrically opposed conclusions: either politics becomes another branch of technology, or technology is recognised as political. The first alternative leads straight to technocracy: public debate will be replaced by technical expertise; research rather than the uninformed opinion of the voters will identify the most efficient course of action... In opposition to this technocratic trend, there is a grand tradition of romantic protest against mechanisation going back a century or more. (Feenberg, 1999:2)

Concurrently, Fry developed his critique of design (Fry, 1992; 1995). He explores craft as ontology, also adopting a Heideggerian critique of the technological displacement of humans. He talked of recentering '...the human maker that advanced technology decentres and displaces. In doing this working life is retained as a "lifeworld" in which the care for "earth" is lived as a practice of making with care... The notion of care goes beyond the common usage of the idea. For Heidegger it became a key existential condition of being...' (Fry, 1992:263). He subsequently writes of our 'ecological crisis' and how we have designed it, driven it and lived it and noting how: 'Design can now more clearly be seen to ride the line between creation and destruction.' (Fry, 1995:190). He also notes that: '...design's acknowledged and celebrated forms have been attached to explicit economic functions and cultural appearances that lack any ability to engage in critical reflection, especially of design's impact on the social and the environmental fabric of our world. (Fry, 1995:190-191. My italics)

International and national technology education developments that informed the critiquing innovation For the field of (D\&)T education itself, the 1990s offered some serious affirmations. Research, although disparate, was growing. At least three internationally-oriented academic journals were established as were five international research conferences. A significant international study of innovations in Technology Education (Layton, 1994) reported: '...(an opportune) moment in curriculum history... In many education systems around the world, irrespective of whether the country is low income and developing or high income and industrialised, the case for technology as a component of general education is under examination and is impelling specific curriculum innovations.' (Layton, 1994:11. My italics)

I add the emphases to point both to Technology Education's zeitgeist and to its legitimation as a dimension of education for all students ('general education'). Layton also reported that: 'School 
technology...is subject to a range of competing influences and the politics of technological literacy who creates and controls the meanings of the phrase, how the imposition of meaning is attempted - is a central concern of technology education today.' (Layton, 1994:13). Furthermore, he documented the complex range of stakeholder interests and associated tensions at play in Technology Education around the world noting six groupings spanning a philosophical-political-social spectrum of interests of such breadth that even the most encompassing curriculum would find challenging to meet.

South Australia embraced these international issues: technology education as general education; contestation over technological literacy; and, stakeholder rivalry - as a genuine curriculum challenge. Early curriculum theorisations (Keirl, 1997a\&b) explored: i) a practical application of the Habermas knowledge interests; ii) the development of a critical technological literacy; and, iii) the potential of critique as a 'partner disposition' to design.

Australia's federal system of government precludes national constitutional power over education which is the prerogative of the six States and two Territories. However, a series of federal collaborations by the respective Ministers of Education (AEC, 1989; MCEETYA, 1999; 2008) established common frameworks, rather than prescriptive detail, for curriculum across the nation. 2010 onwards has seen the gradual emergence of a national curriculum (ACARA, 2015a).

By 1994 eight common 'Learning Areas' had been agreed - each with its own 'Statement' and 'Profile' to describe the coverage and anticipated learning outcomes. This offered, for the first time, national status and a common language for Technology Educators but, at the time, there were over 80 technology subject associations across the country, a bundle in every State and Territory, competing for resources and curriculum space whilst also maintaining scepticism toward local or national partnerships.

Permeating these circumstances ran populist notions of what constituted 'technology' - what I had called 'orthodoxies of technology'. Today, they are less remarkable but still warrant researcher respect. They are that: technologies must be new; technologies are things; technologies are neutral; 'technology' equates 'computers'; technology is applied science; technologies are inevitable; and, Technology is incomprehensible. (Keirl, 1999a:76-77)

\section{The South Australia educational climate}

How then could the complexity described here be managed through good curriculum design? Apart from the international climates for the new curriculum, the educational climate of South Australia warrants description. Critiquing did not simply 'appear' in the emergent D\&T curriculum nor was it ever fashion or fad. Some influence has to be attributed to distinguished critical literacy and curriculum theorists within and beyond the University and Education Department (e.g. Boomer, 1989/1999a\&b; Comber, 1992; 1994; Comber et al., 1998; Johnson \& Reid, 1999; Smyth et al., 2000; Smyth, 2011).

In response to Australia's emergent economic instrumentalism, and advocating innovative constructivist educational practices (over transmissive ones) Boomer wrote: 'Constructivist teachers treat children as if they have brains. They demand students learn to plan and design and construct their own understandings, assisted, of course, by excellent demonstration and instruction at the point of need.' (Boomer, 1989/1999b:78-79). Reflective D\&T practitioners knew that they were already ahead of this game with good design pedagogy. This from a 1994 South Australian Technology Education curriculum guide:

Students demonstrate technological capability by:

- being enterprising, innovative, willing to take considered risks and by exercising critical judgement in developing their ideas;

- demonstrating questioning and critical attitudes to appropriate technological development and application, past, present and future; 
- building a personal set of intellectual tools through experience with a wide range of technological tasks in different contexts;

- developing skills in the use of a range of tools and equipment and developing knowledge about their purposeful uses;

- designing and making a variety of types of technological products and appraising the outcomes.

(DECS, 1994:9. My emphasis)

\section{The South Australian Curriculum, Standards and Accountability (SACSA) Framework}

SACSA is a Birth to Year 12 curriculum and has served South Australia for over fifteen years. Full detail cannot be given here but more is available: on its antecedents in DECS (1995) and AEC

(1994a\&b); on the full curriculum policy at DETE (2001a\&b); and, on D\&T, in Keirl (2000a; 2001a). In taking account of global and local contexts, SACSA articulates:

- a need for curriculum and pedagogies to be dynamic;

- the centrality of an ethical dimension for curricula in changing times;

- recognition that communities and societies no longer exist in isolation;

- its contribution towards an international educational community (Delors, 1996);

- constructivism as its pedagogical theoretical underpinning;

- itself as a Curriculum Framework, that is, not prescriptive but respectful of teachers' professional judgement and local, community-based interpretation;

- seven equity perspectives including those of Aboriginal and Torres Strait Islander peoples; and,

- eight Learning Areas (reflecting those nationally agreed) one being Technology (subsequently, Design and Technology).

Constructivist learning is reinforced through five Essential Learnings (ELs). Applying the postmodern pluralised knowledges and learnings, the ELs are understandings, capabilities and dispositions to be developed through all Learning Areas. 'They are resources which are drawn upon throughout life and enable people to productively engage with changing times as thoughtful, active, responsive and committed local, national and global citizens.' (DETE, 2001b:7; Keirl, 2001a; Spry 2015). The five, with their threads of power, criticality and action, were: Communication; Futures; Identity; Interdependence; and, Thinking.

D\&T's Learning Area design was overseen by an eighteen-member Technology Experts Working Group (TEWG) whose role was not only to meet the curriculum design requirements of SACSA but also to accommodate the Learning Area's special challenges, including: early years-primarysecondary progression; multiple 'subjects' and their competing knowledges; emergent technologies; and continuing transitions from traditional 'technical' towards 'design-rich' pedagogies.

\section{Technological literacy in SACSA}

The following conceptualisation of technological literacy emerged. The influences of Habermas and critical literacy theory are clear:

Technological literacy can be viewed as having three dimensions, all of which are equally valid and important. All students benefit from all dimensions of technological literacy and must not be constrained in their learning to one aspect alone. The three dimensions are:

- the operational, through which students develop skills and competencies at a technical level to use materials and equipment in order to make products and systems (they learn to use and do);

- the cultural, through which students contextualise their learning in the world of designed and made products, processes and systems. They recognise the interdependence of technologies with people.....and they apply their technical learning 
in practical ways to realise designs and solve practical problems (they learn through technology); and,

- the critical, through which students are empowered to take a full and critical role as autonomous citizens in technological societies. They are able to make refined judgements about the worth of the intentions and consequences of technological products, processes and systems on themselves and others...(they learn about, and to be with, technology).

(DETE, 2001a\&b. My italics)

\section{Shifting curriculum orientation from content to process and issues of identity}

Pre-SACSA, Technology Education was organised around four strands: one 'process' strand and three 'content' strands. The process strand of Designing, Making and Appraising (DMA) had been central to all technology activity while three content strands of Information, Materials and Systems were engaged according to the content being taught. Each strand had its own 'strand organisers'. For DMA these were: Investigate, Devise, Produce, Evaluate (IDPE). Pedagogically, both acronyms 'DMA' and 'IDPE' had become props for inappropriate teaching, each inviting linear, step-by-step approaches; implying singular rather than multiple processes; and, inhibiting creative and criticaltransformative design pedagogy.

While the primary sector was already celebrating the power of D\&T to integrate the whole curriculum, the secondary sector nurtured continuing resistance to anything that seemed to threaten multiple, established (often traditional/technical) 'subjects'. This resistance centred on two assumptions: first, that 'subjectification' is necessary because of content differences; and, second, that each subject must have its identity maintained.

However, by common agreement, D\&T was at heart a doing field and this provided the vehicle for a number of key developments, not least that content variations could affirm their home under common process while still maintaining their integrity. By focussing on process in re-designing the strands, primary cross-curricular integration was further strengthened and a (potentially) unifying curriculum umbrella was provided for the secondary players. As a result, only three strands, each a verb, were used to emphasise D\&T process and action. Since the TEWG sought to embrace ethical and futures perspectives, design, particularly in its senses as 'choice' and as 'intention', was confirmed as a powerful vehicle for this. Design was seen as both central to technological activity and as a rich contributor to general education. Both past best practice and perceived curriculum futures saw designing as a worthy strand. Making, although stereotyped towards certain types of manufacturing activity, was confirmed as another fundamental of the field.

\section{The emergence of critiquing}

It was recognised that much valuable D\&T learning emerges from the deconstruction, physical and otherwise, of designed and made products, processes and systems. Students gain much from finding new ways to question, and make new meanings about, their designed worlds. Such considerations, along with those concerning the technological literacy formulation, brought about the innovative strand: critiquing. The three-strand arrangement of Critiquing, Designing and Making (CDM) was seen as wholly inter-dependent to maintain theoretical rigour and to symbolise the necessary holism of quality D\&T education. Notably, the 'C' of critiquing didn't simply replace the 'A' of appraising to become 'DMC'. Rather, an intentional naming disruption was aimed at breaking the linearsequencing of the DMA kind.

D\&T learning in the Age 3-5 phase is also expressed through CDM:

- Children examine, identify and critique processes, products and systems

- Children use their imagination to generate ideas and participate in the processes of design

- Children use materials equipment and processes to design and develop products and systems. 
Of D\&T's eight curriculum aims, four especially call upon critiquing, when students are to develop:

- ethical, critical, enterprising and futures dispositions towards their own and other people's designed and made products, processes and systems;

- capacities to identify and critique the values underlying the intentions, design, manufacture and consequences of any technology;

- capacities to consider and respond to the needs of diverse cultures in relation to developing technologies; and

- capacities to apply their design and technology learning to other Learning Areas, to life in the wider community, virtual community, and in accessing further education and training.

(DETE, 2001a\&b)

This chapter cannot present the detail of the articulation of the SACSA D\&T innovations, that is, the relationships amongst Key Ideas, Standards, Outcomes and more. Nor can it include the interdependent and developmental progression of CDM across the years. Full detail and useful tables can be accessed at DETE, $(2001 \mathrm{a} \& \mathrm{~b})$. However, the six critiquing outcomes indicating the progression of learning from early years to age 17 are, in age order, that the student:

- makes judgments about the significance of different characteristics of products, processes and systems made by themselves and others;

- identifies a range of ways in which the design of everyday products, processes and systems is related to those who use them;

- describes the significance to diverse groups of people of the various criteria used in the design of particular products, processes and systems;

- explains the decisions and choices made in designed and manufactured products, processes and systems and identifies alternative possibilities; and ultimately,

- examines critically the competing values embodied in designed products, processes and systems, clarifies relationships amongst people, products and quality of life and presents ethical analyses of various possible technological futures.

What, then, might be summarised as key achievements of the SACSA D\&T development in terms of critical theory, critical pedagogy, and critiquing? These suggest themselves:

- A properly theorised critical technological literacy that meets multiple curriculum challenges and actor interests in a holistic and integrated way;

- The articulation of that literacy via three interdependent strands all of which are verbs (action words). D\&T was the only Learning Area to achieve this strategy (privileging processes common to all technologies). All other Learning Area strands were content-focussed nouns;

- Design was established as the central general education concept of the Learning Area and became part of its name;

- Critiquing was a true curriculum innovation - a world first for Design and Technology;

- The capacity to readily adapt to such postmodern curriculum arrangements as the five Essential Learnings and their threads of power, criticality and action;

- No single material, technology or subject was named (or valorised over another);

- Because of this, the use of verbs better embraced technological change per se - the curriculum was, itself, sustainable and dynamic; and,

- A disruptive name-ordering of the three CDM strands was designed to erode the DMA/IDPE mantras.

It should be apparent from these achievements that a critical approach was itself key to SACSA Design and Technology's own design process. By this standard, at least, the curriculum had lived up to its own claims. 


\section{Subsequent theorisation and developments}

Critiquing, in D\&T Curriculum, grew out of turn-of-the-Century applications of critical theory articulated as a critical technological literacy for all students. This approach was to serve: 'subjects'; the Learning Area; and, general education alike. However, the intended curriculum is one thing and the enacted curriculum-as-practice is another. Whilst no curriculum is frozen in time, curricula such as SACSA (as a framework) are sustainable because of their capacity for re/interpretation, revision and critique (see e.g. Spry, 2015). All curricula should be open to interrogation and free to evolve. Were they not, in the extreme, they could amount to indoctrination not education.

Over the fifteen years since SACSA's launch, there has been further theorisation and application of critiquing as D\&T curriculum dimension. I close with a selection of six subsequent articulations of critiquing-related curriculum which illustrate the case for its inclusion as an interwoven (not add-on) component of quality D\&T education.

\section{$1 \quad$ Notes on the critiquing- design relationship}

When, in 2002, a colleague questioned the inclusion of critiquing (replacing 'appraising' in DMA) a seed was sown that grew into reflections on the interplay of critiquing and designing in D\&T. Clearly there is overlap, there is interplay and there are differences. As happens, a conference paper helped clarify some thinking. It was suggested that designing amounts to arriving at a 'best defensible compromise' and these conclusions were presented on critiquing:

Critiquing is a skill or a disposition not a methodology. Because it is not concerned with an end point it is used functionally. It needs practice and experience. Critiquing is an excellent tool for arriving at a best defensible compromise (BDC).

Critiquing is responsive to something that exists or has happened - whether an idea in the mind or a physical product. Critiquing is about questioning rather than answering. Its practice helps clarify ill-defined problems through reformulation and reassessment. Critiquing uses many possible differing questions not one best question. Critiquing is reactive - after the fact.

Whilst critiquing is an invaluable tool that enriches designing, it is also something more in itself. Its practice serves democratic purpose and has social value in strengthening democratic society. For D\&T education it helps clarify needs-wants issues, values issues, highlights the contestable, exposes the multiple effects of technologies and becomes a mirror for productive thought and action. Its use focuses not on persons but issues, problems, designs, circumstances and supports values resolution.

Critiquing is deconstructive but not destructive. In itself, it has limited problem-solving capacity but it does have excellent problem-finding or fallacy-exposing capacities. Critiquing acts as quality assurance throughout checking and rechecking validity, integrity, worth, accuracy, and fairness. Critiquing may involve looking in the mirror, reflecting alone or together, or placing in the window for public scrutiny.

Critiquing does not have components to be arranged into lockstep sequences - other than understanding the audience for the critique e.g. self, team, assessor, public. Critiquing may lead to a sharper interrogation of assessment criteria and rationales. Critiquing can be used on one's own methodology of practice - on time management, design procedure chosen or research options taken.

Critiquing aids selection of thinking styles. Thus sophisticated critiquing is a form of metacognition... Critiquing may involve discomfort but that is an aspect of critical purpose. The 'discomfort' of self-critiquing is not a matter of positive or negative criticism. It is a phase of the journey to a BDC. Critiquing as experience-building is the interplay of personal experience and knowledge with others' experience (community, research, opinion etc). The greater the critiquing experience(s) the greater the critical disposition. Critical friendship is an 
asset. Like risk-taking in creativity and designing, risk-taking in critiquing requires safety nets. Critiquing is done against a frame of reference which may be personal experience, some agreed or public criteria, or a design brief.

Imagination should not be critiqued.

(Keirl, 2004:95-96)

The paper suggests that critiquing and designing both:

- develop socially valuable attributes in students;

- develop thinking styles and confidence;

- are valid components of D\&T curriculum for all students;

- are valid components of general democratic education for all students;

- reject fact learning or rote learning;

- are necessary for arriving at a best defensible compromise;

- are undervalued in organisations.

(Keirl, 2004:96)

Meanwhile, these distinct differences were identified:

- critiquing happens after an idea, event, argument, or product. Designing brings into being these circumstances

- designing is pro-active, critiquing re-active

- critiquing is focussed while designing is holistic

- designing always wants imagination to come out and play but critiquing must never knock on imagination's door

So far as their working (or living) arrangement is concerned. Critiquing is a tool which serves the design enterprise. In fact, good designing demands good critiquing.

(Keirl, 2004:96-97)

\section{$2 \quad C D M$ in an alternative arrangement of SACSA}

A second articulation returns to SACSA's five Essential Learnings whose role I have outlined above. (I would nominate ethics, critiquing and design as candidates too.) Such postmodern curricula designs attempt to erode traditional subject silos and avert what Hargreaves (1994) called the balkanisation of the curriculum. I have discussed (Keirl, 2002a) whether the SACSA matrix that positions the eight Learning Areas to be interwoven with five Essential Learnings might not be switched - thus privileging the ELs as the primary curriculum organiser. Such modelling shows that the critiquingdesigning-making rapport could be successfully and robustly articulated through the ELs. However, any version of D\&T without such a rapport (for example, devoid of explicit and interwoven critiquing) would not have the rigour to do so.

\section{Critiquing, discomfort and democratic citizenship}

Critique, as noun and verb, is well established in fields such as the arts and the act of criticising or passing judgement is as applicable to Design and Technology education as it is to life. Critiquing can be learned but it can also be thought of as torment, as opposition, or as being supportive or empathetic (Walton, 1992). How one lives and acts is a matter of one's values; and accommodation of value judgements is the very stuff of active and defensible critique. As Watkins (1978) says:

There are many bad reasons for placing value judgements outside of the boundaries of genuine critical thought, most of them having to do with the idea that criticism should be neutral and descriptive, that it should say what a poem is or what it means before assessing its value and significance...(The) stance of contemplative neutrality is itself indicative of social and class attitude toward human knowledge. (Watkins, 1978:213) 
In the above, 'technology' can be substituted for 'poem' and the orthodoxy of technology-as-neutral is exposed. Walton (1992) describes critical discussion as adversarial and he points to the function of 'critical doubt' in argument which is not '...having a neutral point of view. It is the bracketing or suspending of the point of view you already have, in order to express doubts and questions. But such a suspension does not imply a neutral attitude.' (Walton, 1992:267). He articulates the significance for the critic of becoming '.. truly conscious of his (sic) own act of thinking, the critical act itself assumes a kind of dialectical reciprocity.' Thus, there may never be 'an end' in the practice of critiquing, merely synthesis toward new beginnings. Rather than straitjacketing effect of any singular, linear, step-by-step 'design process', doubt, dialecticism, and craftiness become D\&T curriculum critiquing assets.

With a healthy critical disposition one's value judgements are ever under scrutiny by the uncertain self who, not without discomfort, can bring about new possibilities in both being in, and acting on, the world. As Saul (1995) has argued: 'Criticism is perhaps the citizen's primary weapon in the exercise of her legitimacy. That is why, in the corporatist society, conformism, loyalty and silence are so admired and rewarded; why criticism is so punished and marginalised.' (Saul, 1995:169-170)

Critiquing, properly engaged, must accommodate discomfort (Keirl, 2000b; 2004; 2007a\&b; 2010). Herein lies at once both an educational asset and a pedagogical challenge. Saul (1995) argues the case for valuing and respecting uncertainty as a partner of critique in democracy and he acknowledges discomfort and, in relation to political consciousness: '(T)he virtue of uncertainty is not a comfortable idea, but then a citizen-democracy is built upon participation, which is the very expression of permanent discomfort. The corporatist system depends upon the citizen's desire for inner comfort.' (Saul, 1995:195). More recently, I have described discomfort as one of three 'curriculum characteristics' of sustainable-democratic curriculum (Keirl, 2015a).

D\&T education gives students, through design, real opportunities to be engaged, to participate, and to be creators of their own knowledge but...(they) are (also) practising critique and gaining voice as would-be democratic citizens. This is a strength of quality D\&T as a compulsory curriculum component. For D\&T's intrinsic richness and its general educational role, critiquing must be taken as purposeful and as a democratic tool of debate, values-weighing, social questioning of technocratic cultures of dependence, and so on. (Keirl. 2007a:310)

\section{$4 \quad$ Using critiquing with ethics to explore technologies}

In developing a case for ethical technological literacy (Keirl, 2006) several challenges were to be addressed. The meta-issue of trying to educate about Technology (big-T) is its definition-defying pervasiveness, multistability (Ihde, 2002), multivalence (Sclove, 1995), 'invisibility' (Keirl, 2015c), and more. In an attempt to help 'see' technologies (small-t) I have suggested that any technology might be witnessed through five phases: Intention, Design, Realisation, Use, Consequences which are not discrete but are co-dependent (Keirl, 2009). The phases and their co-dependence are an attempt at exploring $\mathrm{T} /$ technology/ies in ways respect and support holism. Ethical critiquing (or critiquing in general) of a technology at each of its phases is very revealing as circumstances change considerably.

To achieve the democratics of practice needed to know life (in all forms and global sites) with Technology at least two other discourses are enabled through the framing - the ethical, addressing a spectrum from values-weighing to big questions like 'How should we live?; and, critiquing - of one's own and others' design decision-making and technological products, processes and systems. Students with well-developed ethical and critiquing dispositions will be well placed to play a role in democratic life.

(Keirl, 2009:44)

Consideration of others is key to ethical living and we can explore the meta-picture by considering the four realms in which we co-exist (Keirl, 2010): with other people, with other species, with technologies, and with the planet. As individuals we are constructs of our interactions with these four 
realms. However, learning about ethical-democratic life boils down to understanding that we have choices and that these also shape who we are. Critiquing plays its role here too.

Design thinking and choice education for learners in terms of 'me, an individual, and I...as I choose to be and who I choose to spend my time with, and how I choose to present myself to others' is rich in opportunity, so long as the concept of self is recognised as having consequences for others. The pedagogical repertoire of a D\&T teacher can encourage reflection on the self-others-environments relationships and consequences. Using contexts such as design, consumption, and consumerism, with engagement of values, opinions and engagement through active questioning rather than passive acceptance, enables reflection, critique and design activism and develops a higher level of awareness and articulation of choice and consequence.

(Keirl \& McLaren, 2013:1622)

\section{$5 \quad$ Critiquing as thinking tool}

A fifth articulation is that of critiquing as a 'thinking tool' - both for its practical value for the learner engaging design issues and for their broader engagements with the world at large - serving both design intelligence and democratic purpose (Keirl, 2010). It can play a metacognitive role in the selection of thinking styles so necessary to a designerly repertoire (imagining, analysing, researching, synthesising, advocating, are examples). In sum, critiquing:

...is a way of thinking, acting and being. Critiquing is the purposeful, practical and metaphorical deconstruction and analysis of any product, process or system in order to expose the values and intentions behind designs, the unanticipated applications of technologies, and the relationships between people and technologies. As when designing, new meanings and knowledge emerge from critiquing and new realisations emerge for seeing, judging and living in the designed world. (Keirl, 2015a:169)

\section{$6 \quad$ The emergent Australian national curriculum}

At the time of writing, a new national curriculum for Australia is emerging (ACARA, 2015a\&b). All

States and Territories have contributed to this. Critique (and its relations) make some welcome but not well-articulated appearances. Meanwhile, the curriculum's first aim (of five) is that students: 'investigate, design, plan, manage, create and evaluate solutions' (ACARA, 2015b), that is, "IDPEplus", a new six-step linear sequence with a saddening potential for inhibiting critical design pedagogies.

\section{Conclusion}

This chapter has set out something of the motivations, theory, context, history and subsequent developments around the D\&T curriculum innovation of critiquing.

In the closing section I have attempted to show that there is much to be done both to develop the real potential of critiquing in the D\&T curriculum. A start has been made but, I argue, tokenism and vanilla treatments will not do. Those who think that offering a few pluses and/or minuses for this or that technology, design or issue counts as education are doing little of educational value. Critiquing, as presented in this chapter and as part of the South Australian curriculum was a direct response to the complex and contestable political nature both of technologies and of education.

Critiquing and criticism can be conducted anywhere in a rich curriculum but, in Design and Technology, their purposes and practice need proper integration with design pedagogies in order to achieve ethical-critical technological literacy. Critiquing cannot (and ought not to) be considered a part of D\&T education if it is not addressing inequity, injustice, sustainability, or any other ethical issue that arises in any of our four realms of co-existence. The interconnectedness (holism) of critiquing with designing and creating cannot be under-stated. Nor can its role in technological literacy for democratic life be marginalised or diluted by tokenism, reductionism or superficiality. 


\section{Acknowledgement}

I wish to formally acknowledge the dedication, hard work and arguments that every member of the Technology Education Working Group contributed to what was a multi-faceted curriculum design challenge. Their combined effort created a unique and robust D\&T curriculum. Such colleagues, along with all educational researchers, practitioners and teachers who are devoted to achieving better futures for all, stand out against those who would reduce schools to factory production lines and children to products.

\section{References}

Apple, M.W., (1979), Ideology and curriculum, Routledge and Kegan Paul, London.

Apple, M.W., (2001), Educating the "Right" Way: markets, standards, God and inequality, Routledge Falmer, New York.

Aronowitz, S., \& Giroux, H.A., (1993), Education Still Under Siege, (2 ${ }^{\text {nd }}$ Edn.), Bergin \& Garvey, Westport, CT

Australian Curriculum, Assessment and Reporting Authority, (ACARA), (2015a), Development of the Australian Curriculum

http://www.acara.edu.au/curriculum/curriculum design_and development.html

Australian Curriculum, Assessment and Reporting Authority, (ACARA), (2015b), Australian Curriculum: Technologies, URL: http://www.australiancurriculum.edu.au/technologies/introduction

Australian Education Council, (AEC), (1989), Sixtieth Australian Education Council, 14-16 April 1989. Hobart Declaration on Schooling: Common and Agreed Goals for Schooling in Australia, No 7.

Australian Education Council, (AEC), (1994a), A statement on technology for Australian schools, Curriculum Corporation, Carlton.

Australian Education Council, (AEC), (1994b), Technology - a curriculum profile for Australian schools, Curriculum Corporation, Carlton.

Blackmore, J., (2002), 'Speaking out for critical professionalism and education' in Curriculum Perspectives: the Journal of the Australian Curriculum Studies Association, (Sep. 2002), vol 22, No 3, pp.60-62.

Boomer, G., (1989/1999a), 'Democracy, bureaucracy and the classroom' in (Ed.) Green, B., (1999), Designs on Learning: Essays on curriculum and teaching by Garth Boomer, pp101-112, Australian Curriculum Studies Association, Canberra.

Boomer, G., (1989/1999b), 'Education and the Media - Makers or Mirrors? Dilemmas in the development of Australian culture' in (Ed.) Green, B., (1999), Designs on Learning: Essays on curriculum and teaching by Garth Boomer, pp. 71-81, Australian Curriculum Studies Association, Canberra.

Buchanan, I., (2010), A Dictionary of Critical Theory, Oxford University Press, Oxford.

Canby, H.S., (1924/1967), Definitions: Essays in contemporary criticism, Kennikat, Port Washington, NY.

Comber, B., (1992), 'Critical Literacy: a selective review and discussion of recent literature' in South Australian Educational Leader, 3:1 
Comber, B., (1994), 'Critical Literacy: an introduction to Australian debates and perspectives' in Journal of Curriculum Studies, 26:6:655-668

Comber, B., Green, B., Lingard, B. \& Luke, A., (1998), 'Literacy debates and public education: A question of 'Crisis'?' in Going Public; Education Policy and Public Education in Australia, ed. A. Reid, Australian Curriculum Studies Association, SA.

Darder, A., Baltodano, M. P. \& Torres, R. D., (2009a), 'Critical Pedagogy: An introduction' in Darder, A., Baltodano, M. P. \& Torres, R. D., (Eds.), (2009), The Critical Pedagogy Reader, $2^{\text {nd }}$ Edn.), pp.1-20, Routledge, London.

Darder, A., Baltodano, M. P. \& Torres, R. D., (Eds.), (2009b), The Critical Pedagogy Reader, (2 ${ }^{\text {nd }}$ Edn.), Routledge, London.

Delors, J., (1996), Learning: The treasure within, Report to UNESCO of the International Commission on Education for the Twenty-first Century, UNESCO, Paris.

Department for Education and Children's Services, (DECS), (1994), Introducing Technology Education R-7: a guide for teachers, DECS, Adelaide.

Department for Education and Children's Services, (DECS), (1995), Foundation areas of Learning a curriculum framework for early childhood settings, DECS, Adelaide.

Department of Education, Training and Employment (DETE), (2001a), South Australian Curriculum Standards and Accountability Framework (SACSA), URL: http://www.sacsa.sa.edu.au

Department of Education, Training and Employment (DETE), (2001b), South Australian Curriculum Standards and Accountability Framework, (Hardcopy version), DETE Publishing, Adelaide.

Emmitt, M. \& Pollock, J., (1991), Language and Learning, Oxford University Press, Oxford

Feenberg, A., (1991), Critical Theory of Technology, Oxford University Press, Oxford.

Feenberg, A., (1999), Questioning Technology, Routledge, London.

Feenberg, A., (2010), Between Reason and Experience and Experience: Essays in Modernity and Technology, MIT Press, Cambridge, MA.

Freire, P., (1972), Pedagogy of the Oppressed, Penguin, London

Freire, P., (2001), Pedagogy of Freedom: Ethics, Democracy, and Civic Courage, Rowman \& Littlefield, Lanham, Maryland.

Fry, T., (1992), 'Green Hands Against Dead Knowledge' in Ioannou, N., (1992), Craft in Society, An Anthology of Perspectives, Fremantle Arts Centre Press, South Fremantle, WA.

Fry, T., (1995), 'Sacred Design 1: a re-creational theory' in Buchanan, R. \& Margolin, V., (Eds.) (1995), Discovering Design: Explorations in Design Studies, University of Chicago Press, Chicago.

Giroux, H.A., (1983), Theory and Resistance in Education: A Pedagogy for the Opposition, Heinemann Educational Books, London. 
Goodson, I.F. \& Walker, R., (1991), Biography, Identity and Schooling: Episodes in educational research, The Falmer Press, London

Habermas, J., (1971), Knowledge and Human Interests, Beacon, Boston.

Hargreaves, A., (1994), Changing Teachers, Changing Times: Teachers' work and culture in the postmodern age, Cassell, London.

Ihde, D., (2002), Bodies in Technology, University of Minnesota Press, Minneapolis.

Johnson, B. \& Reid, A., (Eds.), (1999), Contesting the Curriculum, Social Science Press, Katoomba.

Keirl, S (1996), Critical Technology Education: Is it? Unpublished Keynote Address to the Technology Teaching and Resource-Based Learning (TTRBL) Conference, $25^{\text {th }}-26^{\text {th }}$ October 1996, Westminster School, Adelaide.

Keirl, S., (1997a), 'Critical Practice in Design and Technology Education: Yarning or weaving?' in Design and Education, October 1997:7:1:3-13

Keirl, S., (1997b), 'Technology Educators and their 'Curriculum Drama': why the profession must be more than mere performers' in South Australian Educational Leader 8:3:Oct.1997:1-12

Keirl, S., (1999/2001), 'As if Democracy Mattered... design, technology and citizenship or 'Living with the temperamental elephant" in (eds.) Norman, E.W.L. \& Roberts, P.H., Design and Technology Educational Research and Curriculum Development: The emerging international research agenda, Loughborough University, Loughborough, U.K.

Keirl, S., (1999a), 'Determining Technology education: knowing the orthodox, the interests, and the potential' in (eds.) Johnson, B. \& Reid, A., (1999) Contesting the Curriculum, pp. 74-89, Social Science Press, Sydney

Keirl, S., (1999b), 'The fruits of Technological Literacy: Wild varieties or crops of mass production' in (eds.) Benson, C. \& Till, W., (1999), Proceedings of Second International Primary Design and Technology Conference, CRIPT, University of Central England, Birmingham.

Keirl, S., (2000a), 'An episode in technology curriculum refinement: it's only another design brief...' in (eds.) Roberts, P.H. \& Norman, E.W.L., Proceedings of the International Conference on Design and Technology Educational Research and Curriculum Development, Loughborough University, Loughborough, U.K.

Keirl, S., (2000b), 'Critiquing as a dimension of technological literacy' in $1^{\text {st }}$ Biennial International Conference on Technology Education Research 2000 Proceedings, Technology Education Research Unit, Griffith University, Qld.

Keirl, S., (2001a), 'Design and Technology and the five 'Essential Learnings' of a new curriculum framework' in (Eds.) Norman, E.W.L. \& Roberts, P.H., (2001), Proceedings of the International Conference on Design and Technology Educational Research and Curriculum Development, Loughborough University, Loughborough, U.K.

Keirl, S., (2001b), 'Parts, hearts and starts in Technology Education: What should it be? What could it be?', Keynote Address to Technology Education Association of Victoria, $\left(18^{\text {th }}\right.$ May 2001) in Technotes Journal, Vol 14, No. 2, Sep 2001.

Keirl, S., (2002a), 'Against the provincialism of customary existence: issues arising from the interplay of 'essential learnings', design and technology and general education' in (Eds.) Middleton, H., 
Pavlova, M., \& Roebuck, D. (2002), Learning in Technology Education: Challenges for the $21^{\text {st }}$ Century, Proceedings of the $2^{\text {nd }}$ Biennial International Conference on Technology Education Research, 5 -7 December 2002, Parkroyal Surfers Paradise, Gold Coast, Queensland, Australia. Centre for Technology Education Research, Griffith University, Qld.

Keirl, S., (2002b), 'Emergent technologies and their potential in the shaping of design and Technology curriculum', in (Ed.) Norman, E.W.L., Proceedings of $1^{\text {st }}$ Design and Technology Association International Research Conference, Coventry, UK, 2nd-5th July 2002, Design and Technology Association, Wellesbourne, UK.

Keirl, S., (2002c), 'Opportunities for Technology Education in the context of globalisation', in (Eds.) Pavlova, M. \& Gurevich, M., (2002), Proceedings of $1^{\text {st }}$ Biennial International Conference on Technology Education, 10-13 July 2002, Nizhny Novgorod, Russia.

Keirl, S., (2004), 'Critiquing and Designing as Keys of Technological Literacy: matters arising from the meeting' in (Eds.) Middleton, H., Pavlova, M. \& Roebuck, D., (2004) Learning for innovation in technology Education: proceedings of the $3^{\text {rd }}$ Biennial International Conference on Technology Education Research, Vol. 2, pp. 91-98, Surfers Paradise, Australia, 9-11, Dec. 2004

Keirl, S., (2006), 'Ethical technological literacy as democratic curriculum keystone' in (Ed.) Dakers, J.R., (2006), Defining Technological Literacy: Towards an epistemological framework, pp 81-102, Palgrave Macmillan, Basingstoke.

Keirl, S., (2007a), 'Critiquing in a democratics of Design and Technology Education' in Dakers, J.R., Dow, W.J. \& de Vries, M. J., (Eds.) (2007), Teaching and Learning Technological Literacy in the Classroom: Proceedings of PATT 18 - International Conference on Design and Technology Educational Research, pp.306-312, Faculty of Education, University of Glasgow, Glasgow.

Keirl, S., (2007b), 'Discomforting the orthodox: four debates used to raise curriculum awareness and promote critical thinking in Design and Technology teacher education', in Norman, E.W.L. \& Spendlove, D., (Eds.), (2007), Linking Learning: Proceedings of the Design and Technology Association International Research Conference 2007, Design and Technology Association, Wellesbourne, UK.

Keirl, S., (2007c), 'The politics of technology curriculum', in (Ed.) Barlex, D., (2007) Design and Technology - For the Next Generation: A collection of provocative pieces, written by experts in their field, to stimulate reflection and curriculum innovation, Nuffield Foundation, UK.

Keirl, S., (2007d), 'Within-it/without-it' and the search for ethical technological literacy.' in Curriculum Perspectives, Vol. 27, No.3, pp.77-80, Sept. 2007, Australian Curriculum Studies Association, Deakin West, ACT.

Keirl, S., (2009), 'Seeing Technology Through Five Phases: a theoretical framing to articulate holism, ethics and critique in, and for, technological literacy' in Design and Technology Education: An International Journal, (2009), Vol 14, No. 3, pp 37-46. URL:

http:/jil.lboro.ac.uk/ojs/index.php/DATE/article/view/1274/1239

Keirl, S., (2010), 'Critiquing and Designing as Thinking Tools for Technology Education for Sustainable Co-existence' in Hansen, R. \& Petrina, S., (Eds.), Proceedings of the Technological Learning and Thinking: Culture, Design, Sustainability, Human Ingenuity Conference, pp 531-540, Vancouver, BC, 17-19 June, 2010. URL:

http://m1.cust.educ.ubc.ca/conference/index.php/TLT/2010/paper/view/57/5

Keirl, S., (2015a), 'Against Neoliberalism; For Sustainable-Democratic curriculum; Through Design and Technology Education', in Stables, K. \& Keirl, S., (Eds.), (2015), Environment, Ethics and 
Cultures: Design and Technology Education's Contribution to Sustainable Global Futures, pp, 153174, Rotterdam, Sense

Keirl, S., (2015b), 'Global ethics, sustainability, and Design and Technology Education', in Stables, K. \& Keirl, S., (Eds.), (2015), Environment, Ethics and Cultures: Design and Technology Education's Contribution to Sustainable Global Futures, pp. 33-52, Rotterdam, Sense

Keirl, S., (2015c), 'Seeing' and 'interpreting' the Human-Technology phenomenon', in Williams, P.J., Jones, A. \& Buntting, C., (Eds.), The Future of Technology Education, pp. 13-34, Springer, Dordrecht.

Keirl, S. \& McLaren, S,V., (2013), 'Students as choice-makers: developing altered consciousness as an aspect of design and global citizenship literacy', in (Eds.), Reitan, J.B., Lloyd, P., Bohemia, E., Nielsen, L.M., Digranes, I. \& Lutnæs, I., Design Learning for Tomorrow: Design Education from Kindergarten to PhD: Proceedings from the 2nd International Conference for Design Education Researchers: (Vols. 1-4), (Design Research Society/CUMULUS the International Association of Universities and Colleges of Art, Design and Media, 14-17 May 2013, Oslo, Norway), Vol. 3, pp. 1611-1625, ABM-media/Oslo and Akershus University College of Applied Sciences, Oslo.

Kellner, D., 'Critical Theory', in Curren, R., (Ed.), (2003), A Companion to the Philosophy of Education, pp.161-175, Blackwell, Oxford.

Kemmis, S., (1991/2005), 'Emancipatory action research and postmodernisms'in Marsh, C. (Ed.), (2005), Curriculum Controversies: point and counterpoint 1980 - 2005, pp.308-318, Australian Curriculum Studies Association, Deakin West, Australian Capital Territory.

Kincheloe, J. L., (2008/2010), Knowledge and Critical Pedagogy: An Introduction, Springer, Springer.com.

Lankshear, C., (1998), 'Frameworks and workframes: literacy policies and new orders' in Unicorn, 1998:24:2:43-58

Layton, D., (Ed.), (1994), 'A School Subject in the Making? The Search For Fundamentals', in Layton, D., (Ed.), (1994), Innovations in Science and Technology Education, Vol. V., pp. 11-28, UNESCO, Paris.

Luke, A., (1992), 'Literacy and Work in 'New Times" in Open Letter, Vol.3, No.1, pp.3-15.

McLaren, P., (1989/2009), 'Critical Pedagogy: A look at the major concepts', in Darder, A., Baltodano, M. P. \& Torres, R. D., (Eds.), (2009), The Critical Pedagogy Reader, (2 ${ }^{\text {nd }}$ Edn.), pp.61-83, Routledge, London.

Ministerial Council on Education, Employment, Training and Youth Affairs (MCEETYA), (1999), National Goals for Schooling in the Twenty-First Century, URL:

http://www.curriculum.edu.au/mceetya

Ministerial Council on Education, Employment, Training and Youth Affairs (MCEETYA), (2008), Melbourne Declaration on Educational Goals for Young Australians, MCEETYA Secretariat, Carlton, Vic. URL:

http://www.curriculum.edu.au/verve/ resources/national declaration on the educational goals for $y$ oung australians.pdf

Morris, V C, (1966/1990), Existentialism in education: what it means, Waveland Press, Prospect Heights, Ill. 
Morrison, K., (2001). 'Jürgen Habermas', in Palmer, J.A., (Ed.), (2001), Fifty Modern Thinkers on Education: From Piaget to the Present, pp.215-224, Routledge, London.

New London Group, The (1996), ‘A Pedagogy of Multiliteracies: Designing Social Futures', in Harvard Educational Review Spring 1996:66:1:60-92

Petrina, S., (2000a), 'The Political Ecology of Design and Technology Education: An inquiry into methods' in International Journal of Technology and Design Education, 10, 207-237.

Petrina, S., (2000b), 'The Politics of Technological Literacy' in International Journal of Technology and Design Education, 10, 181-206.

Petrina, S., (2003), 'Human Rights and Politically Incorrect Thinking versus Technically Speaking' in Journal of Technology Education, Spring 2003:14:2:70-74

Pinar, W.F., (Ed.), (2003), International Handbook of Curriculum Research, Lawrence Erlbaum Associates, Mahwah, NJ.

Pinar, W.F., (2004/2008), What is Curriculum Theory? Routledge, New York.

Pinar, W.F., (2007), Intellectual Advancement Through Disciplinarity: Verticality and Horizontality in Curriculum Studies, Sense, Rotterdam.

Postman, N., (1999/2000), Building a Bridge to the Eighteenth Century: How the past can improve our future, Scribe Publications, Carlton North, Vic.

Postman, N. \& Weingartner, C., (1969/1971), Teaching as a Subversive Activity, Penguin, Harmondsworth.

Reid, A., (2004/2005), 'Challenging the dominant Grammars of an Undemocratic Curriculum' in Marsh, C. (Ed.), (2005), Curriculum Controversies: point and counterpoint 1980 - 2005, pp. 97-105, Australian Curriculum Studies Association, Deakin West, Australian Capital Territory.

Saul, J.R., (1995), The Unconscious Civilisation, Anansi, Toronto.

Sclove, R.E., (1995), Democracy and Technology, The Guilford Press, N.Y.

Smith, D.G., (2003), 'Curriculum and Teaching Face Globalization', in Pinar, W.F., (Ed.), (2003), International Handbook of Curriculum Research, pp. 35-51, Lawrence Erlbaum Associates, Mahwah, NJ.

Smith, D.L. and Lovat, T.J., (1991), Curriculum: Action on Reflection, Social Science Press, Sydney.

Smith, D.L. and Lovat, T.J., (2006), Curriculum: Action on Reflection, $\left(4^{\text {th }}\right.$ Edn.), Thomson/Social Science Press, South Melbourne.

Smyth, J., (2011), Critical Pedagogy for Social Justice, Continuum, New York.

Smyth, J., Dow, A., Hattam, R., Reid, A. \& Shacklock, G., (2000), Teachers' Work in a Globalizing Economy, Falmer Press, London.

Spry, L., (2015), 'Opening up the Four Walls: Reflections on Two South Australian ESD Projects' in Stables, K. \& Keirl, S., (Eds.), (2015), Environment, Ethics and Cultures: Design and Technology Education's Contribution to Sustainable Global Futures, pp, 285-298, Rotterdam, Sense. 
van Manen, M., (1990), Researching Lived Experience: Human Science for an Action Sensitive Pedagogy, State University of New York Press, London, Ontario.

Walton, D., (1992), The Place of Emotion in Argument, The Pennsylvania State University Press, Pennsylvania.

Watkins, E., (1978), The Critical Act: criticism and community, Yale University Press, London. 